"Accountability in the Ghanaian local governance structure: probing the role of external auditing"

\begin{tabular}{|c|c|}
\hline AUTHORS & $\begin{array}{l}\text { Haruna Maama D https://orcid.org/0000-0003-4943-5489 } \\
\text { Ferina Marimuthu (D https://orcid.org/0000-0001-9205-8127 }\end{array}$ \\
\hline ARTICLE INFO & $\begin{array}{l}\text { Haruna Maama and Ferina Marimuthu (2020). Accountability in the Ghanaian } \\
\text { local governance structure: probing the role of external auditing. Problems and } \\
\text { Perspectives in Management, } 18(4), 475-485 \text {. doi:10.21511/ppm.18(4).2020.38 }\end{array}$ \\
\hline DOI & http://dx.doi.org/10.21511/ppm.18(4).2020.38 \\
\hline RELEASED ON & Friday, 25 December 2020 \\
\hline RECEIVED ON & Friday, 09 October 2020 \\
\hline ACCEPTED ON & Thursday, 03 December 2020 \\
\hline LICENSE & $\begin{array}{l}(c) \text { EY } \\
\text { This work is licensed under a Creative Commons Attribution } 4.0 \text { International } \\
\text { License }\end{array}$ \\
\hline JOURNAL & "Problems and Perspectives in Management" \\
\hline ISSN PRINT & $1727-7051$ \\
\hline ISSN ONLINE & $1810-5467$ \\
\hline PUBLISHER & LLC “Consulting Publishing Company "Business Perspectives" \\
\hline FOUNDER & LLC "Consulting Publishing Company "Business Perspectives" \\
\hline$\sigma^{\circ}$ & $\begin{array}{l}\text { 三: } \\
\text { 三: }\end{array}$ \\
\hline NUMBER OF REFERENCES & NUMBER OF FIGURES \\
\hline 39 & 1 \\
\hline
\end{tabular}

(c) The author(s) 2023. This publication is an open access article. 


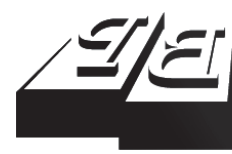

BUSINESS PERSPECTIVES

(O)

LLC "CPC "Business Perspectives" Hryhorii Skovoroda lane, 10, Sumy, 40022, Ukraine www.businessperspectives.org
Received on: $9^{\text {th }}$ of October, 2020 Accepted on: $3^{\text {rd }}$ of December, 2020 Published on: $25^{\text {th }}$ of December, 2020

(C) Haruna Maama,

Ferina Marimuthu, 2020

Haruna Maama, Ph.D. in Accounting, Lecturer, Faculty of Accounting and Informatics, Department of Management Accounting, Durban University of Technology, South Africa. (Corresponding author)

Ferina Marimuthu, Ph.D. in Finance, Senior Lecturer, Faculty of Accounting and Informatics, Department of Management Accounting, Durban University of Technology, South Africa.

\section{ACCOUNTABILITY IN THE GHANAIAN LOCAL GOVERNANCE STRUCTURE: PROBING THE ROLE OF EXTERNAL AUDITING}

\begin{abstract}
The roles of external auditors have been under the spotlight due to the strategic positions they occupy to ensure accountability by public sector managers. This study examines the role of the external auditors in the accountability regime of the Ghanaian local governance structure. The study analyzed the annual reports of the Auditor General (AG) on all the metropolitan, municipal, and district assemblies (MMDAs) in Ghana from 2010 to 2018 through a content analysis method. The analysis revealed that Ghanaian audit activities had mainly focused on internal control effectiveness, cash management, contract management, revenue management, expenditure management, payroll management, and procurement management. However, the study found that the focus of the external auditors kept expanding as the years progressed. The evidence showed that the auditors excluded performance audits in their scope of work. The findings of the study further revealed that the MMDAs had recurring, repetitive, and common audit queries, comprising cash; procurement and stores; contract and tax irregularities. Besides, the audit recommendations were in response to the specific audit queries on the various financial and operational irregularities. Based on the analysis, the study concludes that the external auditing in Ghana has marginally contributed to accountability in the MMDAs. The study recommends that the scope of the external audit should include performance auditing.
\end{abstract}

Keywords

JEL Classification accountability, external audit, public sector, Ghana, cash irregularities, procurement irregularities, performance audit

G32, M41, M42

\section{INTRODUCTION}

There is an increase in public demand for accountability from public servants at all levels. This has emerged from the greater acceptance of democratic values and traditions around the globe. As a result, the Government of Ghana and other public sector management stakeholders have shown increased recognition of the contributions made by Public Sector Auditing (PSA) towards accountability, performance, and the fight against corruption (Asiedu \& Deffor, 2017). At first glance, the idea of holding public servants accountable seems attractive. However, a closer look unravels several issues that require discussion and policy recommendations for making the concept of accountability of public servants operational. Government is, however, aware that proper accountability will lead to the success of government programs and activities (Christie, 2018). Lack of adequate accountability has a high tendency to undermine governments' efforts to improve the standard of living. As a result, the Ghana Audit Service was established under the Audit Service Act, 2000 (Act 584) to ensure proper accountability among government-controlled institutions. 
The Ghanaian Auditor-General (AG) of office has been at the front and center in the discussion over the issue of accountability. It might barely be otherwise, given that the AG's office is an agent of the state that functions with a substantial level of independence from government. Hence, public sector auditing in Ghana has gained much attention from the Government of Ghana, politicians, civil society organizations (CSO), donor agencies, and the general public. Many budgetary allocations and resources are always made available to the AG department to execute its work effectively. However, the AG has highlighted irregularities in spending public money in his annual reports every year. While the AG's office considers itself a body fundamental to the efforts for elevating accountability in the public sector, others consider it a manifestation of corrupt activities of governments' constitutional practice. The underlining conundrum is that different individuals perceive the effectiveness and ability of the AG through different lenses. This conundrum is present despite the AG's specific responsibilities and powers stated in Article 187(2) of the 1992 Constitution of Ghana. This has occasioned a discussion on how an external auditor contributes to proper accountability, especially considering that the intended function of the external audit is to lend credibility to financial reports.

Extant literature such as those of Hyndman and McConville (2018), Anand and Sossin (2018), Abidin and Singaravelloo (2018), and Royo et al. (2019) indicate an increasing body of research on public sector accountability and auditing. However, the paucity of such studies in Ghana is evident. This study thus examines the external auditors' role in the accountability regime of Ghanaian local governance structure. The content analysis method is employed to achieve three objectives: to track and examine the focus of external audit concerning accountability in Ghana from 2010 to 2018; to evaluate the nature and trend of audit queries as a signal of accountability and to assess the audit recommendations and its implications on accountability. The study found that the external auditing regime in Ghana had mainly focused on internal control effectiveness, cash management, contract management, revenue management, expenditure management, payroll management, and procurement management. However, the focus of the external auditors kept expanding as the years progressed.

\section{LITERATURE REVIEW}

The public requires full accountability from those elected and appointed to handle and manage public monies and resources (Zinyama, 2013; Rosa \& Morote, 2016). Ntim et al. (2016) also hold that public resources ministers, elected members and managers, and other officials must account for the resources under their care. In this context, public sector auditing is expected to be an essential nexus in the chain of accountability. This is so because Hay and Cordery (2018) and Yang and Northcott (2019) maintain that auditing strengthens accountability, both outwardly through to the elected officials who provide the monies and outwardly through to the beneficiaries, taxpayers, and the public.

The term accountability has been defined differently by various authors from different perspectives. First, Ferry and Murphy (2018) define accountability as being answerable to someone or a group of people for performing specific tasks necessary to fulfill duties, responsibilities, and other charges.
In the opinion of Royo et al. (2019), accountability is the commitment and obligations of individuals or entities assigned with public resources to be answerable for the financial, managerial, and program responsibilities given to them report to those that gave them the responsibilities. Simply put, the concept of accountability involves someone being held responsible for his/her actions by somebody in a predetermined and prescribed form. Underlying in these definitions is the idea that individuals trusted with public funds had a legal responsibility to report how they were allocated with resources, how they used the resources, and the results accomplished from using the resources (Winyama, 2013; Tooley \& Hooks, 2020). The discussion highlights that accountability is the foundation of good public financial management (Suprihastini et al., 2017; Siverbo et al., 2019). The apparent construct from the definitions of accountability is that accountability is present in any form of relationship where one party called an agent performs some tasks for another party, called a principal. In the context of the public sec- 
tor, public officers are the agents, and the citizens are principals (Blair, 2018).

At the core of accountability is auditing. Extant literature document the role of auditing towards public sector accountability. For instance, in Spain, Rosa and Morote (2016) also reported that external auditing had resulted in effective accountability. Another study conducted by Kristin et al. (2015) showed that external auditing positively influences accountability in Europe. This is an indication that external auditing is instrumental in maintaining accountability in the public sector. Similarly, Reichborn-Kjelnnerud and Vabo (2017) investigated the role of external auditing play in the accountability framework in Norway. Through the examination of audit reports, the authors found that editing contributes to accountability.

In a related study, Gustavson and Sundstrom (2018) examined the impact of quality auditing on public sector accountability in 100 countries. The authors demonstrated that quality auditing has a positive influence on public sector accountability and eventually reduce corruption. This confirms the idea that auditing can contribute to the effective functioning of the public sector. Tumwebaze et al. (2018) also investigated the contribution of auditing to accountability in 92 public statutory firms in Uganda. The authors used a regression estimation technique to show that auditing is a significant predictor of public sector accountability.

Other streams of literature in Africa also confirms that auditing has a positive effect on public sector accountability. For instance, in Nigeria, Okpala (2012) also investigated auditors' contribution to public sector accountability. The authors used content analysis to analyze five years of the Auditor General's annual reports and found that a weak auditing framework has resulted in low accountability in Nigeria. This demonstrates that an effective audit can lead to a properly functioning public sector. Like this finding, Appah and Bariweni (2013) assessed the effect of public sector auditing on public sector accountability in Nigeria. Appah and Bariweni's (2013) findings showed that auditing and accountability are positively related. This suggests that auditing is fundamental to maintaining accountability in the public sector.
A study conducted in Uganda by Bananuka et al. (2017) also showed that auditing significantly contributes to accountability in the public sector. Cumbe and Inácio (2018) used a case study approach to examine how external auditing influences the Common Fund of the Mozambique Institute of Statistics' accountability. The evidence provided by Cumbe and Inácio (2018) showed a positive and significant relationship between auditing and accountability. This finding implies that an effective and independent external auditing can contribute to the effective discharge of accountability in the public sector. Like these studies, Jachi and Yona (2019) assessed the impact of the independent audit function on transparency and accountability in the Zimbabwean public sector. Using a semi-structured questionnaire and regression analysis, the authors showed that auditing is positively associated with transparency and accountability in the Zimbabwean public sector. This finding agrees with a view that auditing provides a valuable tool to achieve accountability in the public sector. The previous studies' findings imply that external auditing is a useful instrument towards discharging accountability duty in the public sector.

Over the past twenty years, Ghana has pursued ambitious initiatives to reform the public sector. These programs include initiatives aimed at strengthening democratic political governance and improving accountability in the public sector. According to Gordon and Betley (2011), there have been significant successes gained, yet challenges remain. Concerning the scrutiny and oversight of the public sector's financial activities, Ghana serves as a role model for many African countries (Fabrini, 2017). This is because Ghana has been a stable democratic country since 1992, which has resulted in the sustained strengthening of its institutions. Besides, Ghana practice the government's majoritarian system, which has a separate presidential, legislative, and judicial system. This has ensured that the major institutions that contribute to effective accountability in the public sector enjoy some degree of independence. However, Ganghof (2018) maintains that government interference and override of structures and policies obstruct the country's accountability regime. These arrangements influence the institutional environment within which the Public Account 
Committee (PAC) of Parliament and the Ghana Audit Service (GAS) operate and take care of some of the challenges with public sector management and accountability (Ganghof, 2018).

\section{AIMS}

The aim of the study is to examine the role of the external auditors in the accountability regime of the Ghanaian local governance structure. The specific objectives include the following:

1. To track and examine the focus of external audit concerning accountability in Ghana.

2. To evaluate the nature and trend of audit queries as a signal of accountability.

3. To assess the audit recommendations and their implications on accountability.

\section{THEORETICAL FRAMEWORK}

This study is conducted within the framework of the principal-agent model of accountability proposed by Mitnick (1982). This theory assumes that the country is led and managed by a benevolent dictator (the principal); hence, the principal's key objective is to motivate other government officials (agents) to act with integrity in the use of public resources. This hypothesis has believed in the 'wrongdoing and discipline' hypothesis, which opines that public authorities are considered accountable when the costs (discipline) related to the wrongdoing of non-accountability and other degenerate acts surpass the benefits (Blair, 2018). In this way, given the crime-punishment relationship, the principal can guarantee accountability by lessening the number of exchanges over which public authorities have discretions. There are two varieties of this theory: the state without and with the officials (Blair, 2018). In a state without legislators' variety, accountability can be guaranteed by the rules-driven government that incorporates reliable internal controls with practically no space for discretion by public officials (agents). In any case, the suitability of this approach is in exceptionally corrupt nations, where the enforcers of the rules themselves add additional weight to corruption and absence of discretion is obstructed by collusive conduct by corruptors has been tested.

The second variety of this theory coordinates legislators' roles and elected officials in the analysis of corruption (Gustavson \& Sundstrom, 2015). The authors contended that the elected officials and legislators are representatives of the nationals. Their part is to check the excesses of the principal for the benefit of the citizens and improve the accountability relationship. However, Vosselbarn (2016) contends that in corrupt countries, policies and enactment are manipulatively organized for specific interest groups (representing the interests of the private sector or individual units of public bureaucracy going after higher spending plans) in return for rents or side payments. The author maintains that legislators measure the advantages of being non-accountable (the individual monetary benefits from corrupt practices and enhanced chance of re-election) against the costs (the possibility of being caught, punished, and losing an election with a tarnished reputation) to settle on a choice. Similarly, Fisher (2004) explains that the choice to compromise accountability and lessen corruption has various variables. This involves campaign financing mechanisms; access to information by voters; the capacity of residents to vote out corrupt officials; the level of political contestability; the sort of electoral framework; the democratic establishments and conventions set up, and the organizations of accountability in governance.

\section{RESEARCH METHODOLOGY}

The study adopted the qualitative research method based on a descriptive research approach. Since this study sought to examine the role of external auditors in the accountability regime of Ghanaian local governance structure, there was the need to adopt a descriptive research design such that the phenomenon could be better explained. A secondary source of data was derived for eight (8) years from the annual reports of the AG of Ghana from 2010 to 2018. The population of the study comprised the MMDAs in Ghana. The year 2018 was chosen as the end year of the annual reports because it was the last year with the readily available annual report of the AG. The researchers down- 
loaded the annual reports from the website of the Audit Service of Ghana.

\subsection{Data collection instruments}

The role of external auditors towards accountability in the district assemblies is empirically tested through a content analysis of the annual reports of the AG from 2010 to 2018 based on the evaluation matrix. Content analysis is accepted as the most appropriate method of analyzing annual reports' textual content (Hossain et al., 2015). This research method has been used widely to inquire into textual data analysis. It is considered a valid technique for gathering data that involves codifying qualitative information in anecdotal and literary form into categories to derive themes of varying levels of complexity. Data analysis was done using thematic content analysis. Consequently, the researcher read and reread the content of the annual reports and established various themes and trends concerning the focus of the external audit, the categories of queries, and the nature of recommendations offered by the external auditors in their audit reports.

During the reading of the annual reports, the researchers adopted an interpretation, and to some extent, critical textual analysis of their contents to extract a range of themes. These themes were developed through an interpretative analysis based on observing, reading, and rereading the annual reports. This activity provided a range of images of changes and trends in the external audit reports from 2010 to 2018. The content and significant findings on accountability in the annual reports of the AG were collected, organized into themes, presented, and analyzed based on three major sections: the focus of the audit over the years, the irregularities and queries raised over the years; and the nature of recommendations provided by the AG.

\section{RESULTS AND DISCUSSION}

\subsection{The focus of external audit concerning accountability}

The analysis of the content of the external audit reports from 2010 to 2018 showed that the focus of the external audit activities was guided by
Section 13 of the Audit Service Act 2000 (Act 854) and the auditing standards of the International Organisation of Supreme Audit Institutions (INTOSAI). The audit activities mainly focused on the examination of the accounts of the MMDAs. Specifically, the audit activities had primarily focused on areas which included internal control effectiveness, cash management, contract management, revenue management, expenditure management, payroll management, and procurement management. However, it was realized that the focus of the external auditors kept expanding as the years progressed. For instance, the Auditor General's Report (2011, p. 1) stated among other things the following as the main focus of its audit: "the audits were guided by Section 13 of the Audit Service Act, 2000 (Act 584) and the auditing standards of the International Organisation of Supreme Audit Institutions (INTOSAI)". The AG's report further stated that the audits were done to express his/her opinion on the financial statements of the MMDAs on the following:

- whether the accounts have been properly kept;

- whether all the money collected by the MMDAs had been accounted for properly, consistent with the required regulations, rules, and procedures;

- whether money was spent for the purposes for which they were given and all expenditures were backed by proper authorization;

- whether the required records were kept and that the existing rules and procedures were sufficient to protect and control the assets of the MMDAs;

- whether the programs and activities of the MMDAs had been conducted in respect of value for money.

The external auditors examined the financial accountability issues concentrating on expenditure, revenue, assets, and cash management. The audit activities also focused on the internal control effectiveness of the MMDAs. The findings generally point out that the external auditing of the accounts and activities of the MMDAs in Ghana appears to respond to three critical issues of ac- 
countability. These include financial accountability, legal adherence, and internal control effectiveness. What was missing was performance accountability. The audit reports failed to report the effectiveness with which the resources given to the MMDAs were utilized. Besides, the reports failed to provide information on how the internal processes of the MMDAs ensured the effective use of resources. The external audit activities mainly concentrated on how resources were used, rather than the assessment of the evaluation of the assemblies' performance.

However, the refusal of the external audit to focus on the performance of the Audit Service Act 2000 (Act 854) was not surprising because the duties of the AG are well spelled out in the 1992 Constitution of Ghana and the Audit Service Act, 2000 (Act 854). This might be due to the complexity of performance audit, inadequate expertise, and lack of resources available to the External Audit Agency to undertake this task. The external audit reports widely reported a lack of financial resources, logistical resources, and expertise to undertake performance audits. However, looking at the increasing influence of the performance audit, it was expected that the external audit would have also focused on a performance audit.

\subsection{The nature and trend of audit queries as a signal of accountability}

The analysis of the annual reports of the AG on the activities of the MMDAs revealed that they had recurring, repetitive, and common audit queries. In most cases, it was realized that the queries in the audit reports were quoted verbatim, with just the figures or amounts changing. The audit report organized these queries into four categories: cash irregularities; procurement and stores irregularities; contract irregularities and tax irregularities. Table 1 summarizes the various irregularities and queries from the audit activities from 2010 to 2018. The various queries issued by the AG reports from 2010 to 2018 are subsequently explained and discussed.

The annual reports analysis has clearly shown that the MMDAs observed common repeated audit queries throughout the years. The repeated and re- curring of the same audit queries for the observed years indicate that there was accountability failure on the part of officials responsible for addressing the irregularities. These queries primarily arose as a result of governance ineffectiveness. This points to a lack of or ineffective internal control systems, weak internal audit unit, and poor performance of the audit committee among the MMDAs. This is because internal control systems and internal audit units ensure adherence to laid down procedures and effective use of resources. This means that establishing the internal audit units among the MMDAs, which was aimed to eliminate or minimize these challenges, has yet to achieve its envisioned purposes.

The analysis further points out that the MMDAs lacked the required expertise to carry out their tasks. This is because some essential procurement and accounting practices were executed with many mistakes and infractions. The reason for these procurement infractions may be ascribed to the self-serving attitude of some of the staff of the MMDAs, negligence, or a genuine mistake. One particular issue that occurred regularly in the Auditor General's annual reports involved outstanding imprest, where imprests were not regularly retired. This indicates that the staff lacked the skills and knowledge to retire their imprests. Similar to this, several problems were found with the management of procurement and contract. Some of the specific infractions of procurement and contract management included procurement without competitive bidding, procurement of goods and services without the approval of the Public Procurement Authority, paying for goods which were not delivered, the value of stores inappropriately or not recording in the books, and lack of proper documentation of project and contracts.

The above observations reflect the failure on the part of the management of the MMDAs to honor their accountability responsibilities. These irregularities occurred because of the lack of punishment given to the management of the MMDAs concerned. However, the evidence indicates that occasionally, the Public Account Committee (PAC) of Parliament and the Ministry of Local Government take disciplinary measures to deter these irregularities' subsequent occurrence. Some of the disciplinary measures taken by the PAC in- 
Source: Ghana Auditors General Reports (2010-2018).

\begin{tabular}{|c|c|c|c|c|}
\hline \multirow{2}{*}{ Queries } & \multicolumn{4}{|c|}{ Summary of specific irregularities } \\
\hline & $2010-2011$ & 2012 & 2013 & 2014-2018 \\
\hline \multirow{8}{*}{ Cash irregularities } & I. Unaccounted funds & I. Unaccounted funds & I. Unaccounted funds & I. Unaccounted funds \\
\hline & li. Unretired imprest & i. Unretired imprest & i. Unretired imprest & li. Unretired imprest \\
\hline & lii. Unpaid rent & lii. Unpaid rent & lii. Unpaid rent & lii. Unpaid rent \\
\hline & \multirow{5}{*}{ Iv. Judgment debt } & $\begin{array}{l}\text { iv. Overdeductions made by the administrator } \\
\text { of the DACF }\end{array}$ & $\begin{array}{l}\text { iv. Overdeductions made by the } \\
\text { administrator of the DACF }\end{array}$ & $\begin{array}{l}\text { iv. Over deductions made by the administrator } \\
\text { of the DACF }\end{array}$ \\
\hline & & V. Judgment debt & V. Judgment debt & V. Judgment debt \\
\hline & & Vi. Unbudgeted expenditure & Vi. Unbudgeted expenditure & Vi. Unbudgeted expenditure \\
\hline & & \multirow{2}{*}{ Vii. Payments without receipts } & Vii. Unearned salaries & Vii. Unearned salaries \\
\hline & & & Viii. Payments without receipts & Viii. Payments without receipts \\
\hline \multirow{6}{*}{ Procurement irregularities } & $\begin{array}{l}\text { i. Payments for items } \\
\text { not delivered }\end{array}$ & i. Payments for items not delivered & i. Payments for items not delivered & i. Payments for items not delivered \\
\hline & $\begin{array}{l}\text { ii. Sole sourcing without } \\
\text { approval from the PPA }\end{array}$ & ii. Sole sourcing without approval from the PPA & $\begin{array}{c}\text { ii. Sole sourcing without approval from } \\
\text { the PPA }\end{array}$ & ii. Sole sourcing without approval from the PPA \\
\hline & $\begin{array}{l}\text { iii. Procurement from } \\
\text { not-VAT registered } \\
\text { entities }\end{array}$ & iii. Procurement from not-VAT registered entities & $\begin{array}{l}\text { iii. Procurement from not-VAT registered } \\
\text { entities }\end{array}$ & $\begin{array}{l}\text { iii. Procurement from not-VAT registered } \\
\text { entities }\end{array}$ \\
\hline & \multirow{3}{*}{$\begin{array}{l}\text { iv. Failure to account for } \\
\text { issued items }\end{array}$} & lii. Uncompetitive procurement & lii. Uncompetitive procurement & lii. Uncompetitive procurement \\
\hline & & $\begin{array}{l}\text { Iv. Execution of contracts that were not captured } \\
\text { in the procurement plan }\end{array}$ & \multirow[t]{2}{*}{ Iv. Failure to account for issued items } & $\begin{array}{l}\text { Iv. Execution of contracts that were not } \\
\text { captured in the procurement plan }\end{array}$ \\
\hline & & V. Failure to account for issued items & & v. Failure to account for issued items \\
\hline \multirow{3}{*}{ Tax irregularities } & $\begin{array}{l}\text { i. Failure to deduct } \\
\text { withholding tax }\end{array}$ & I. Failure to deduct withholding tax & I. Failure to deduct withholding tax & I. Failure to deduct withholding tax \\
\hline & $\begin{array}{l}\text { ii. Failure to obtain VAT } \\
\text { invoice }\end{array}$ & ii. Failure to obtain VAT invoice & ii. Failure to obtain VAT invoice & ii. Failure to obtain VAT invoice \\
\hline & $\begin{array}{l}\text { iii. Failure to remit taxes } \\
\text { withheld to GRA }\end{array}$ & iii. Failure to remit taxes withheld to GRA & iii. Failure to remit taxes withheld to GRA & iii. Failure to remit taxes withheld to GRA \\
\hline \multirow{4}{*}{ Contract irregularities } & i. Lack of accountability & i. Lack of accountability & i. Lack of accountability & i. Lack of accountability \\
\hline & $\begin{array}{l}\text { ii. Overpayment of } \\
\text { contracts }\end{array}$ & ii. Overpayment of contracts & ii. Overpayment of contracts & ii. Overpayment of contracts \\
\hline & $\begin{array}{l}\text { iii. Abandonment of } \\
\text { contracts }\end{array}$ & iii. Abandonment of contracts & iii. Abandonment of contracts & iii. Abandonment of contracts \\
\hline & $\begin{array}{l}\text { iv. Low quality of } \\
\text { contracts outputs }\end{array}$ & iv. Low quality of contracts outputs & iv. Low quality of contracts outputs & iv. Low quality of contracts outputs \\
\hline
\end{tabular}


clude the issuance of warning letters, surcharge, and the transfer of the officials involved. In rare and extreme cases, the delinquent officials are demoted and prosecuted. However, given that these infractions and the queries keep occurring yearly, there is an indication that some of these disciplinary measures and the auditors' recommendations have not adequately addressed the problem, hence failed to achieve the intended outcome. A striking observation is that the magnitude of the amount involved keeps increasing. This suggests that external auditing has not adequately contributed to the discharge of accountability in the Ghanaian local government.

\subsection{External audit recommendations and its implications on accountability}

The analysis of the annual reports of the AG on the activities of the assemblies revealed that the audit recommendations were provided on issues such as cash irregularities; procurement and stores irregularities; contract irregularities, and tax irregularities. These recommendations were in response to the specific audit queries issued regarding various financial and operational irregularities. Besides, the audit recommendations were generic, recurring, repetitive, and shared throughout the years. Most of the recommendations were provided verbatim among the years. Mainly, analogous recommendations were provided for almost the whole period under review, suggesting that most of the recommendations were not sufficiently acted upon by the officials responsible for their implementation. Consequently, nearly all the MMDAs had outstanding recommendations that have not been implemented. In most cases, the AG repeated the need for the MMDAs to ensure the implementation of the audit recommendations.

Generally, the empirical evidence gathered from the study points out that the external auditing of the accounts and activities of the MMDAs in
Ghana provided valuable information that can enhance accountability. However, the response of the management of the MMDAs had not been impressive. This is because the management of the MMDAs repeatedly refused to implement the recommendations of the external auditors, thus making such recommendations repetitive throughout the years. This might result from a lack of skilled staff and sanctions and punishments to the responsible officials for the irregularities. In this case, the contribution of external auditing towards accountability was constrained by the inability of the MMDAs to implement the audit recommendations.

Based on the analysis, it can be put forward that external auditing has marginally contributed to accountability in the MMDAs. This is because external auditing provided valuable information and recommendations that could enhance accountability. Besides, the auditing had limited scope because it failed to adequately report on the performance of the various programs and policies implemented by the various MMDAs. However, the refusal or the inability of the officials responsible for their implementation limited the effectiveness of the external auditing to contribute to accountability. These results agree with the findings of earlier studies. For instance, the findings agree with those of Cumbe and Inácio (2018) who found that several external auditors' challenges limited their ability to promote accountability in the public sector. Similarly, Zinyama (2013) and Okpala (2012) reported that the administrative and legislative framework of external auditing in Zimbabwe and Nigeria, respectively, had loopholes and thus made it ineffective to enhance accountability. On the contrary, Appah and Bariweni (2013) who examined the effectiveness of auditing of local government accounts in Nigeria to ensure accountability disagreed with these findings and concluded that external auditing provided proper accountability in the local governance structure of Nigeria.

\section{CONCLUSION}

The study revealed that the focus of the external audit activities was guided by Section 13 of the Audit Service Act 2000 (Act 854) and the auditing standards of the International Organisation of Supreme Audit Institutions (INTOSAI). The study further found that the audit activities mainly focused on ex- 
amining the accounts of the MMDAs. The main focus of the external audit activities of the MMDAS is the examination of the accounts of the MMDAs. The audit activities' focus was internal control effectiveness, cash management, contract management, revenue management, expenditure management, payroll management, and procurement management. Besides, the focus of the external auditors expanded as the years progressed. The queries on the auditing of the MMDAs were recurring and repetitive and were categorized into cash; procurement and stores; contract and tax irregularities. Moreover, the external auditors' recommendations related to issues such as cash irregularities; procurement and stores irregularities; contract irregularities and tax irregularities. These recommendations were mainly in response to the specific audit queries issued regarding the various financial and operational irregularities. Based on the analysis, it is concluded that external auditing has marginally contributed to accountability in the assemblies. This paper offers critical practical implications for policy formulation and revision regarding the external audit function.

\section{AUTHOR CONTRIBUTIONS}

Conceptualization: Haruna Maama.

Data curation: Haruna Maama.

Formal analysis: Haruna Maama, Ferina Marimuthu.

Funding acquisition: Haruna Maama, Ferina Marimuthu.

Investigation: Haruna Maama, Ferina Marimuthu.

Methodology: Haruna Maama.

Project administration: Haruna Maama, Ferina Marimuthu.

Validation: Ferina Marimuthu.

Visualization: Haruna Maama, Ferina Marimuthu.

Writing - original draft: Haruna Maama, Ferina Marimuthu.

Writing - review \& editing: Haruna Maama, Ferina Marimuthu.

\section{REFERENCES}

1. Abidin, N. Z. B. Z., \& Singaravelloo, 4. Asiedu, K. F., \& Deffor, E. W. K. (2018). The Effects of Loyalty to Accountability and Public Trust in Local Government Service Delivery. International Journal of Business and Management, 2(1), $1-6$.

2. Anand, A., \& Sossin, L. (2018). Independence and accountability in public and private governance. Canadian Public Administration, 61, 15-35. Retrieved from https://www.researchgate.net/ publication/324891937_Independence_and_accountability_in_ public_and_private_governance_ public_and_private_governance

3. Appah, E., \& Bariweni, B. (2013). An Examination of the Effectiveness of Auditing of Local Government Financial Reports in Bayelsa State, Nigeria. Current Research Journal of Social Sciences, 5(2), 45-53. Retrieved from https:// maxwellsci.com/print/crjss/v5-4553.pdf

\section{(2017). Fighting Corruption} By Means Of Effective Internal Audit Function: Evidence From The Ghanaian Public Sector. International Journal of Auditing, 21, 82-99. Retrieved from https://www.researchgate.net/ publication/312203787_Fighting_Corruption_by_Means_of Effective_Internal_Audit_Function_Evidence_from_the_Ghanaian_Public_Sector_Fighting_Corruption_by_Means_of_Effective_ Internal_Audit_Function

5. Auditor General's Report. (2011). Report of The Auditor General on The Accounts of District Assemblies for The Year Ended 31 December 2010. Accra, Ghana.

6. Auditor General's Report. (2012). Report of The Auditor General on The Accounts of District Assemblies for The Year Ended 31 December 2011. Accra, Ghana.
Retrieved from https://ghaudit. org/web/wp-content/uploads/ Reports/2011/REPORT-OFTHE-AUDITOR-GENERAL-ONTHE-MANAGEMENT-ANDUTILISATION-OF-DISTRICTASSEMBLIES\%E2\%80\%99COMMON-FUND-DACFAND-OTHER-STATUTORYFUNDS-FOR-THE-YEAR-ENDED-31-DECEMBER-2011.pdf

7. Auditor General's Report. (2013). Report of The Auditor General on The Accounts of District Assemblies for The Year Ended 31 December 2012. Accra, Ghana. Retrieved from https://ghaudit.org/web/wpcontent/uploads/Reports/2012/ REPORT-OF-THE-AUDITORGENERAL-ON-THE-PUBLICACCOUNTS-OF-GHANACONSOLIDATED-FUND-FORTHE-YEAR-ENDED-31-DECEMBER-2012.pdf 
8. Auditor General's Report. (2014). Report of The Auditor General on The Accounts of District Assemblies for The Year Ended 31 December 2013. Accra, Ghana. Retrieved from https://ghaudit.org/web/wpcontent/uploads/Reports/2013/ REPORT-OF-THE-AUDITORGENERAL-ON-THE-PUBLICACCOUNTS-OF-GHANA-MINISTRIES-DEPARTMENTS-ANDOTHER-AGENCIES-MDAs-FORTHE-YEAR-ENDED-31-DECEMBER-2013.pdf

9. Auditor General's Report. (2015). Report of The Auditor General on The Accounts of District Assemblies for The Year Ended 31 December 2014. Accra, Ghana. Retrieved from https://docplayer. net/188286306-Report-of-theauditor-general-on-the-accounts-of-district-assemblies-forthe-financial-year-ended-31-december-2014.html

10. Auditor General's Report. (2016). Report of The Auditor General on The Accounts of District Assemblies for The Year Ended 31 December 2015. Accra, Ghana. Retrieved from https://ghaudit. org/web/wp-content/uploads/ Reports/2015/REPORT-OF-THEAUDITOR-GENERAL-ON-THEACCOUNTS-OF-DISTRICTASSEMBLIES-FOR-THE-FINANCIAL-YEAR-ENDED-31-DECEMBER-2015.pdf

11. Auditor General's Report. (2017). Report of The Auditor General on The Accounts of District Assemblies for The Year Ended 31 December 2016. Accra, Ghana. Retrieved from https://ghaudit. org/web/wp-content/uploads/ Reports/2016/REPORT-OF-THEAUDITOR-GENERAL-ON-THEACCOUNTS-OF-DISTRICTASSEMBLIES-FOR-THE-FINANCIAL-YEAR-ENDED-31-DECEMBER-2016.pdf

12. Auditor General's Report. (2018). Report of The Auditor General on The Accounts of District Assemblies for The Year Ended 31 December 2017. Accra, Ghana. Retrieved from https://ghaudit. org/web/wp-content/uploads/ Reports/2017/REPORT-OF-THEAUDITOR-GENERAL-ON-THE-
ACCOUNTS-OF-DISTRICTASSEMBLIES-FOR-THE-FINANCIAL-YEAR-ENDED-31-DECEMBER-2017.pdf

13. Auditor General's Report. (2019). Report of The Auditor General on The Accounts of District Assemblies for The Year Ended 31 December 2018. Accra, Ghana. Retrieved from https://ghaudit.org/web/ wp-content/uploads/2020/02/REPORT-OF-THE-AUDITOR-GENERAL-ON-THE-ACCOUNTSOF-DISTRICT-ASSEMBLIESFOR-THE-FINANCIAL-YEARENDED-31-DECEMBER-2018. pdf

14. Bananuka, J., Nkundabanyanga, S. K., Nalukenge, I., \& Kaawaase, T. (2018). Internal Audit Function, Audit Committee Effectiveness and Accountability in the Ugandan Statutory Corporations. Journal of Financial Reporting and Accounting, 16(1), 138-157. https:// doi.org/10.1108/JFRA-07-20160062

15. Blair, H. (2018). Citizen Participation and Political Accountability for Public Service Delivery in India: Remapping the World Bank's Routes. Journal of South Asian Development, 13(1), 54-81. https://doi.org/ 10.1177\%2F0973174118760942

16. Christie, N. V. (2018). A comprehensive accountability framework for public administrators. Public Integrity, 20(1), 80-92. https://doi.org/10.10 80/10999922.2016.1257349

17. Cumbe, L. L., \& Inácio, H. (2018). The Impact of External Audit on the Accountability of the Common Fund of the Mozambique National Institute of Statistics. Managerial Auditing Journal, 33(6/7), 538-557. https:// doi.org/10.1108/MAJ-01-20171500

18. Fabbrini, S. (2017). Which Democracy for a Union of States? A Comparative Perspective of The European Union. Global Policy, 8, 14-22. https://doi. org/10.1111/1758-5899.12486

19. Ferry, L., \& Murphy, P. (2018). What about Financial Sustainability of Local
Government: A Critical Review of Accountability, Transparency, And Public Assurance Arrangements in England During Austerity. International Journal of Public Administration, 41, 619-629. Retrieved from https://dro.dur. ac.uk/20526/

20. Fisher, E. (2004). The European Union in the Age of Accountability. Oxford Journal of Legal Studies, 24(1), 495-515. Retrieved from https://www.jstor. org/stable $/ 3600565$ ?seq $=1$

21. Ganghof, S. (2018). A New Political System Model: SemiParliamentary Government. European Journal of Political Research, 57(2), 261-281. https:// doi.org/10.1111/1475-6765.12224

22. Gordon, A., \& Betley, M. (2011). Evaluation of Public Financial Management Reform in Ghana 2001-2010: Desk Report, Fiscus/ Mokoro. Oxford.

23. Gustavson, M., \& Sundstrom, S. (2018). Organising the Audit Society: Does Good Auditing Generate Less Public Sector Corruption? Administration \& Society, 50(10), 1508-1532. https://doi.org/ 10.1177\%2F0095399716674306

24. Hay, D., \& Cordery, C. (2018). The Value Of Public Sector Audit: Literature And History. Journal of Accounting Literature, 40, 1-15. https://doi.org/10.1016/j.acclit.2017.11.001

25. Hossain, M., Hecimovic, A., \& Choudhury Lema, A. (2015). Corporate Social and Environmental Responsibility Reporting Practices from an Emerging Mobile Telecommunications Market. Australian Accounting Review, 25(4), 389-404. Retrieved from https://www.researchgate.net/ publication/287356332_Corporate_Social_and_Environmental_ Responsibility_Reporting_Practices_from_an_Emerging_Mobile Telecommunications_Market

26. Hyndman, N., \& McConville, D. (2018). Trust and accountability in UK charities: Exploring the virtuous circle. The British Accounting Review, 50(2), 227- 
237. https://doi.org/10.1016/j. bar.2017.09.004

27. Jachi, M., \& Yona, L. (2019). The Impact of Independence of Internal Audit Function on Transparency and Accountability. Case of Zimbabwe Local Authorities. Research Journal of Finance and Accounting, 10(5), 64-77. Retrieved from https:// www.semanticscholar.org/paper/ The-Impact-of-Independenceof-Internal-Audit-on-and-JachiYona/c81b669aa692a11b12ec98c04f68ed41c9e60b23

28. Mitnick, B. M. (1982). Regulation and the Theory of Agency. Review of Policy Research, 1, 442-453. https://doi. org/10.1111/j.1541-1338.1982. tb00448.x

29. Ntim, C. G., Soobaroyen, T., \& Broad, M. J. (2017). Governance Structures, Voluntary Disclosures and Public Accountability: The Case of UK Higher Education Institutions. Accounting, Auditing \& Accountability Journal, 30, 65-118. https://doi.org/10.1108/ AAAJ-10-2014-1842

30. Okpala, K. E. (2012). Fiscal Accountability Dilemma in Nigeria Public Sector: A Warning Model for Economic Retrogression. Research Journal of Finance and Accounting, 3(6), 113-131. Retrieved from https:// www.iiste.org/Journals/index.php/ RJFA/article/view/2407

31. Rosa, C. P., \& Morote, R. P. (2016). The Audit Report as an Instrument for Accountability in Local Governments: A Proposal for Spanish Municipalities. International Review of Administrative Sciences, 82, 536-558. Retrieved from https://www.researchgate. net/publication/277888462_ The_audit_report_as_an_instrument_for_accountability_in_ local_governments_a_proposal_ for_Spanish_municipalities

32. Royo, S., Yetano, A., \& GarcíaLacalle, J. (2019). Accountability Styles in State-Owned enterprises: The good, the bad, the ugly... And the pretty. Revista de ContabilidadSpanish Accounting Review,
22(2), 156-170. Retrieved from https://www.researchgate.net/ publication/334160381_Accountability_Styles_in_State-Owned_ enterprises_The_good_the_bad_ the_ugly_and_the_pretty

33. Siverbo, S., Cäker, M., \& Åkesson, J. (2019). Conceptualising dysfunctional consequences of performance measurement in the public sector. Public Management Review, 21(12), 1801-1823. https:// doi.org/10.1080/14719037.2019.1 577906

34. Suprihastini, E., Akram, A., \& Santoso, B. (2017). Effect Of Regional Financial Accounting System, Internal Control Systems and Regional Financial Audit on Financial Accountability of Local Government. E-Proceeding Site Mandala. Retrieved from https://www.semanticscholar.org/ paper/EFFECT-OF-REGIONALFINANCIAL-ACCOUNTINGSYSTEM\%2C-AND-SuprihastiniAkram/0a4b8af0663a4431afalcc52 59676abb8ce34093

35. Tooley, S., \& Hooks, J. (2020). Accounting for volunteers: Enhancing organisational accountability and legitimacy. Nonprofit and Voluntary Sector Quarterly, 49, 93-112. https://doi.org/10.1177\%2F0899764019853041

36. Tumwebaze, Z., Mukyala, V., Ssekiziyivu, B., Tirisa, C. B., \& Tumwebonire, A. (2018). Corporate Governance, Internal Audit Function and Accountability in Statutory Corporations. Cogent Business \& Management, 5(1), 1-13. Retrieved from https://www.researchgate.net/ publication/327901348_Corporate_governance_internal_audit_function_and_accountability_in_statutory_corporations

37. Vosselbarn, E. (2016). Accounting, Accountability, and Ethics in Public Sector Organizations: Toward a duality between Instrumental Accountability and Relational Responsibility. Administration \& Society, 48(5), 602-627. https://doi.org/10.1177\%2F0095399713514844
38. Yang, C., \& Northcott, D. (2019). How can the public trust charities? The role of performance accountability reporting. Accounting \& Finance, 59(3), 16811707. https://doi.org/10.1111/ acfi. 12475

39. Zinyama, T. (2013). Efficiency and Effectiveness in Public Sector Auditing: An Evaluation of the Comptroller and Auditor General's Performance in Zimbabwe from 1999 to 2012. International Journal of Humanities and Social Science, 3, 118-126. Retrieved from http:// www.ijhssnet.com/journals/Vol_3_ No_7_April_2013/29.pdf 